\title{
Developing Students' Intercultural Competence in Foreign Language Textbooks
}

\author{
Paweł Sobkowiak \\ Adam Mickiewicz University, Poznań, Poland
}

\begin{abstract}
If learners are to communicate effectively in a foreign language (FL), they have to know not only the language with its intricate system and conventions, but also, to some degree, their interlocutors' cultural background, since language is also a cultural phenomenon which cannot be properly understood without the cultural context in which it is used. Globalization has led to changes in students' needs concerning FL learning. To cater to them, intercultural capabilities have to be incorporated into language education-learners have to be involved in observing, describing, and comparing different cultures rather than only learn passively about the target foreign culture(s). This paper reports on the findings of research aiming to check whether textbooks used for teaching English as a foreign language (EFL) in Polish schools reflect an intercultural approach, i.e., to what extent their cultural components go beyond depicting the target culture or various cultures and involve students in exploring, analyzing, and comparing the cultures, thus sensitizing their intercultural perception, awareness, and appreciation. The study revealed that the textbooks do this in a very limited way, and their capacity to foster intercultural teaching and learning is quite small and limited.
\end{abstract}

Keywords: intercultural teaching and learning, developing intercultural competence, EFL textbooks

\section{Introduction}

Language is used to communicate something beyond itself. Hence, foreign language (FL) teaching should go beyond a linguistic code, because forms and structures of the language will not suffice to enable effective communication (Kramsch, 1993; 2008). In intercultural interactions, people make cultural assumptions that arise from their own cultural backgrounds. According to Byram (1988), language does not function independently from the context in which it is used. The meaning of any particular utterance is not determined solely by its linguistic composition; speakers' cultural backgrounds influence it considerably. Thus, to interpret one's message appropriately, the cultural context in which it has been created has to be taken into consideration. ${ }^{1}$

Cultures structure reality differently, and as a result, behaviors differ across countries. For example, when it comes to introducing oneself, in the U.S. (individualistic culture), where emphasis is placed on personal achievements, what a person does is often accentuated, while in Mexico (collectivistic culture), where relationships are highly valued, people introduce themselves in terms of family names and these relationships

Paweł Sobkowiak, Ph.D., senior lecturer, School of Law and Administration, Adam Mickiewicz University.

1 A dialogue between an American manager and his Greek team member shows how different values and attitudes surface in conversations and can lead to miscommunication (Dignen \& Chamberlain, 2009, p. 154). 
(Kohls \& Knight, 1994, pp. 23-24).

People raised in the same culture share the same set of cultural practices and an understanding of the meanings associated with the language in use, and hence, their language use is shaped accordingly by these shared understandings. Cultural conditioning results in people viewing situations in predetermined ways, and students should be aware that their responses are not universal across the globe, but typical of the ones considered appropriate in their native cultures. Without such knowledge, understanding foreigners is hard to achieve. Some people, despite their considerable FL proficiency, still have problems with communicating in it successfully.

If learners want to understand representatives of foreign cultures, firstly they have to realize that they are products of enculturation, i.e., their perception of the world and a range of accepted behaviors have been shaped by the surrounding culture, and so have the accepted norms they conform to and the values they hold. Secondly, they have to be able to find similarities and differences between cultures, and in intercultural contacts resort to the former and try to find and explain the reasons for the latter. Students should be encouraged to observe, analyze, and interpret the behaviors of foreigners, and compare them with the norms and conventions of their own cultures, hoping to grasp perception and appreciation of the difference. This will help them notice and understand better the diversity of the world; develop empathy, open-mindedness, mindfulness, and respect for others; and increase their chances for successful intercultural communication.

Currently, the paradigm of teaching culture in a FL classroom has changed-for example, in the case of English, which has gained a status of lingua franca, it has been postulated that it should be taught as an international language in an intercultural perspective. ${ }^{2}$ It has even been argued that students do not need to internalize the cultural norms of the British or American cultures anymore, because they will not be of much help in contact with the citizens of the world.

The aims of an intercultural approach have been summarized in the Common European Framework of Reference for Languages as follows: “... It is a central objective of language learning to promote the favorable development of the learner's whole personality and sense of identity in response to the enriching experience of otherness in language and culture" (Council of Europe, 2001, p. 1). The intercultural perspective in language education challenges one of the well-established goals of FL teaching, which used to be achieving native-like proficiency by students. First, such an objective is in fact unattainable for the majority of learners, and second, seems unjustifiable and unnecessary, since, as it has been mentioned before, students will use it more often in contacts with its non-native speakers.

In intercultural learning and teaching, linguistic goals are complemented by developing intercultural competence and the skills required for cultural exploration and mediation. Separation of English as an international language from any particular culture and adopting the intercultural perspective imposes on English textbook writers specific requirements - cultural content should go beyond a mere presentation of the English-speaking countries, such as Great Britain, the U.S., or Australia, and cover a wide range of other cultural contexts, the students' one included.

However, interculturality cannot be equated solely with the representation of many cultures. What lies at the heart of the intercultural approach is learners' active involvement in exploring, analyzing, and comparing

\footnotetext{
${ }^{2}$ Liddicoat and Scarino (2013) claimed that since FL learners bring more than one language and culture to the process of meaning-making and interpretation, language learning per se is intercultural in its nature (p. 2).
} 
cultures, so that they can learn about the system of values used by other people often perceived as strangers, and thus, develop intercultural sensitivity and the skills necessary to mediate whenever differences in understanding occur. It is also supposed to contribute to students' wider perception and appreciation of the differences between cultures, distancing them from ethnocentrism and preventing evaluation of foreigners from their native cultural perspective, which often provides a strong impediment to cross-cultural understanding.

\section{Research-Rationale, Aim, and Methodology}

This paper seeks to examine the potential of English as a foreign language (EFL) textbooks used in Poland for intercultural teaching and learning, i.e., for preparing learners for cross-cultural communication. The reason for undertaking the research was the author's interest in adapting intercultural teaching and learning to the Polish context, where the majority of students had gone through a largely mono-cultural socialization into homogenous classrooms. Few cultural minorities inhabit the country and teachers are mostly Polish graduates of local English departments. Consequently, students have access mostly to cultural worldviews similar to their own and cannot experience the difference between their own perception and that of people who originate from different cultural backgrounds.

In such a situation, developing students' intercultural competence seems to be extremely important. It is in the FL classroom that learners should attain the ability to put together, and thus, experience cultural differences as preparation for intercultural communication in which they will get involved. If this cannot be achieved by direct contacts with multicultural classmates or a teacher from a diverse culture, it should be compensated by appropriate intercultural content in textbooks which can, to a certain degree, make up for this deficiency.

The research aimed at investigating the cultural content of ELT textbooks used in Polish high schools. It focused on the textbooks used in Poland, since it was part of a larger project which attempted to assess whether intercultural competence was developed in FL classrooms in the Polish context. ${ }^{3}$ The study was meant to answer the following specific questions concerning EFL textbooks, namely, whether they helped learners to:

1. Explore foreign cultures, and, thus, increase learners' positive attitudes toward otherness;

2. Contrast and compare cultures, investigate cultural differences (increase learners' awareness of the problems that arise in communicating with foreigners);

3. Develop socio-cultural pragmatic abilities;

4. Explore their own culture (to acknowledge their own cultural identity and increase awareness of having specific cultural values and unstated cultural assumptions);

5. Reflect on their values, attitudes, and beliefs, and those of foreigners;

6. Explore non-verbal communication across cultures;

7. Become conflict mediators.

A content analysis of 20 EFL textbooks (see Appendix) was carried out in the summer of 2015. Six titles targeted at high school students aged 15 to 18 were examined: Oxford Matura Trainer (two levels), New Matura Explorer (four levels), Matura Prime Time Plus (four books), New English File (four levels), Matura Solutions (four books), and Framework (two levels). Most of the textbooks (except New English File) have a seal of approval granted by the Polish Ministry of Education and are recommended for use in Polish EFL

3 The findings of the previous studies were published in Sobkowiak (2012a; 2012b; 2013; 2014; 2015). 
classrooms, so they can be considered as constituting a representative sample.

The books were selected at random. A mixed-methods approach of quantitative and qualitative data collection was applied. First, following a thorough study of the literature on intercultural learning and teaching, a list of 10 most typical intercultural task-types was compiled. Second, in the quantitative part of the study, all the textbooks were examined in search of the identified activities. A reading passage oriented on a specific cultural issue with a set of exercises which accompanied it, i.e., a reading comprehension exercise, a vocabulary exercise, and a listening passage with a follow-up comprehension exercise, were treated as one example of an activity aiming at exploring culture (one recording in the table). A separate, single task designed for learners to write a short passage, preceded by their individual searches of the available sources, was also given one time.

The main concern was to count the frequency of intercultural exercises in the analyzed textbooks. To increase validity of the results, the sample was double-checked for the intercultural content. The data collection and the analysis of the cultural material were conducted by the author of the article. All the books were considered separately to allow identifying the ones with the highest numbers of intercultural tasks.

At the qualitative stage of the study, the material related to various cultures in the sample was analyzed, i.e., all the texts with the accompanying exercises and the context in which they appeared. This was done to consider the nature of cultural presentations and their contexts. Since not all cultural information can possibly be integrated in a given volume and it is not enough to enumerate what is (or is not) there, also considered was how a given cultural input could be used to sensitize students to intercultural awareness and appreciation.

\section{Results and Discussion}

Most of the examined books have a separate section devoted to teaching culture where diverse cultures are presented and explored (except for the New English File series and Oxford Matura Trainer). However, the content reflects a culturalist perspective-elements of the intercultural approach appear very rarely. The distribution of intercultural activities in the sample is shown in Tables 1-6.

Table 1

Distribution of Intercultural Exercises in New Matura Explorer

\begin{tabular}{|c|c|c|c|c|}
\hline $\begin{array}{ll}\text { Exercise type } & \text { Level } \\
\end{array}$ & Elementary & Pre-intermediate & Intermediate & Upper-intermediate \\
\hline Exploring foreign cultures & 4 & - & 5 & 8 \\
\hline Ethnographic project & - & - & - & - \\
\hline Contrasting and comparing cultures & 1 & 1 & 1 & 2 \\
\hline "Critical incident" & - & - & - & - \\
\hline Developing learners' socio-cultural pragmatic abilities & - & - & - & - \\
\hline Exploring learner's culture & 1 & 6 & 2 & 7 \\
\hline Reflecting on values, attitudes, and beliefs & - & - & - & 5 \\
\hline Exploring non-verbal communication & - & - & - & - \\
\hline Interpreting visual and verbal cultural representations & 1 & - & - & 1 \\
\hline Conflict mediation & - & - & - & - \\
\hline Total & 7 & 7 & 8 & 23 \\
\hline
\end{tabular}


Table 2

Distribution of Intercultural Exercises in New Matura Solutions

\begin{tabular}{|c|c|c|c|c|}
\hline $\begin{array}{ll}\text { Exercise type } & \text { Level } \\
\end{array}$ & Elementary & Pre-intermediate & Intermediate & Upper-intermediate \\
\hline Exploring foreign cultures & 11 & 13 & 8 & 4 \\
\hline Ethnographic project & - & - & - & - \\
\hline Contrasting and comparing cultures & - & 2 & - & - \\
\hline "Critical incident" & - & - & - & - \\
\hline Developing learners' socio-cultural pragmatic abilities & - & - & - & - \\
\hline Exploring learner's culture & 4 & 4 & 1 & - \\
\hline Reflecting on values, attitudes, and beliefs & - & - & 2 & - \\
\hline Exploring non-verbal communication & - & 1 & - & - \\
\hline Interpreting visual and verbal cultural representations & - & - & - & - \\
\hline Conflict mediation & - & - & - & - \\
\hline Total & 15 & 20 & 11 & 4 \\
\hline
\end{tabular}

Table 3

Distribution of Intercultural Exercises in Matura Prime Time Plus

\begin{tabular}{lcccc}
\hline Exercise type & Elementary & Pre-intermediate & Intermediate & Upper-intermediate \\
\hline Exploring foreign cultures & 3 & 8 & 2 & 4 \\
Ethnographic project & - & - & - & - \\
Contrasting and comparing cultures & 6 & 2 & 3 & - \\
"Critical incident" & - & - & - & - \\
Developing learners' socio-cultural pragmatic abilities & - & - & - & - \\
Exploring learner's culture & 5 & 12 & 2 & - \\
Reflecting on values, attitudes, and beliefs & 1 & - & - & - \\
Exploring non-verbal communication & 1 & - & - & - \\
Interpreting visual and verbal cultural representations & 1 & - & - & - \\
Conflict mediation & - & - & 7 & 8 \\
\hline Total & 17 & 22 & - \\
\hline
\end{tabular}

Table 4

Distribution of Intercultural Exercises in New English File

\begin{tabular}{|c|c|c|c|c|}
\hline $\begin{array}{ll}\text { Exercise type } & \text { Level } \\
\end{array}$ & Elementary & Pre-intermediate & Intermediate & Upper-intermediate \\
\hline Exploring foreign cultures & 5 & 2 & - & 2 \\
\hline Ethnographic project & - & - & - & - \\
\hline Contrasting and comparing cultures & - & - & 2 & - \\
\hline "Critical incident" & - & - & - & - \\
\hline Developing learners' socio-cultural pragmatic abilities & - & - & - & - \\
\hline Exploring learner's culture & - & - & - & - \\
\hline Reflecting on values, attitudes, and beliefs & - & - & - & 2 \\
\hline Exploring non-verbal communication & - & - & - & - \\
\hline Interpreting visual and verbal cultural representations & - & - & 1 & 1 \\
\hline Conflict mediation & - & - & - & - \\
\hline Total & 5 & 2 & 3 & 5 \\
\hline
\end{tabular}


Table 5

Distribution of Intercultural Exercises in Framework and Oxford Matura Trainer

\begin{tabular}{|c|c|c|c|c|}
\hline Exercise type $\quad$ Level & $\begin{array}{l}\text { Framework } \\
\text { (Elementary) }\end{array}$ & $\begin{array}{l}\text { Framework } \\
\text { (Pre-intermediate) }\end{array}$ & $\begin{array}{l}\text { Oxford Matura } \\
\text { Trainer } \\
\text { (Ordinary) }\end{array}$ & $\begin{array}{l}\text { Oxford Matura } \\
\text { Trainer } \\
\text { (Advanced) }\end{array}$ \\
\hline Exploring foreign cultures & 10 & 5 & 1 & 3 \\
\hline Ethnographic project & - & - & - & - \\
\hline Contrasting and comparing cultures & - & - & 1 & - \\
\hline "Critical incident" & - & - & - & - \\
\hline Developing learners' socio-cultural pragmatic abilities & - & - & - & - \\
\hline Exploring learner's culture & 1 & - & 1 & 1 \\
\hline Reflecting on values, attitudes, and beliefs & - & 1 & - & - \\
\hline Exploring non-verbal communication & - & - & - & - \\
\hline Interpreting visual and verbal cultural representations & - & - & - & - \\
\hline Conflict mediation & - & - & - & - \\
\hline Total & 11 & 6 & 3 & 4 \\
\hline
\end{tabular}

Table 6

The Overall Distribution of Intercultural Exercises in the Investigated Textbooks

\begin{tabular}{lr}
\hline Exercise type & $N$ \\
\hline Exploring foreign cultures & 98 \\
Ethnographic project & - \\
Contrasting and comparing cultures & 21 \\
"Critical incident" & - \\
Developing learners' socio-cultural pragmatic abilities & - \\
Exploring learner's culture & 51 \\
Reflecting on values, attitudes, and beliefs & 11 \\
Exploring non-verbal communication & 2 \\
Interpreting visual and verbal cultural representations & 5 \\
Conflict mediation & - \\
\hline Total & 188 \\
\hline
\end{tabular}

The analyzed textbooks most often encourage their users to explore foreign cultures ( 98 recordings). However, there are two books in which not even a single such exercise can be found (New Matura Explorer [Pre-intermediate] and New English File [Intermediate]). The distribution of this activity type in the sample ranges from 1 to 13. However, none of the textbooks contains ethnographic projects, which could provide students with the unrivalled opportunities to explore and analyze cultures. In most cases, exploring cultures happens implicitly-learners are expected to read a text on a specific aspect of a foreign culture, and do the accompanying exercises focusing mostly on a comprehension check or vocabulary practice. Students are not expected to explore anything on their own, nor are they given any tasks requiring observing, analyzing or assessing any element of a foreign culture. Consequently, they do not have much chance to realize how multi-dimensional any culture is.

Quite a number of the exercises are very superficial, and although they refer learners to their culture, they do not encourage exploring it in depth. For example, while exploring famous artists Pablo Picasso and Vincent Van Gogh (New Matura Solutions [Elementary]), students are asked to write a short text about another artist, writer, or musician. This will involve searching various sources for information. However, in the book, this is 
not preceded by any discussion of the features that have made both artists famous, how the perception of fame has changed over the years and what it looks like across cultures. Without this, not much intercultural learning will take place.

The second most common intercultural activities found in the sample provide learners with opportunities to explore their own culture (51 times). Their distribution ranges from 1 to 12 . However, in as many as six books, such exercises do not appear at all (30\% of the sample). In only four books do students have an opportunity to explore their native culture five times and more $(20 \%)$. This reveals that even if there are activities referring students to their own culture, they do not work on this frequently enough, nor on a regular basis, so consequently the chances for them to be released from the confinements of ethnocentrism are very low. The exercises are very superficial. Not a single exercise was found, which would give students an opportunity to look at well-known Polish practices from a different perspective than the Polish one. Naturally, people do not observe others from any other viewpoint than that determined by their own cultural conditioning. Kohls and Knight (1994) claimed that in cross-cultural communication, people often have to "detach themselves from their usual behaviors and mindsets and to stand back and gain a different perspective" (p. 66). The analyzed textbooks do not make this possible-learners are not invited to look afresh at their home culture, nor can see themselves as others might see them.

The third most frequent intercultural activities in the analyzed textbooks focus on comparing and contrasting cultures (21 recordings). Their distribution in the sample ranges from one to six. However, in as many as 10 textbooks, such tasks do not appear at all (50\% of the sample). What is quite surprising is that the book with the most frequent distribution of this exercise type is for beginners (Matura Prime Time Plus [Elementary]), which buries the myth, as if exploring cultures required a high level of language proficiency. Furthermore, in four books for upper-intermediate and advanced levels, such tasks have not been included at all ( $20 \%$ of the sample).

Critical incidents and specific exercises aiming at comparing and contrasting cultures do not appear in the sample at all. They become something that requires an impulse on the part of the student to analyze in detail intercultural encounters and aim to explain the reasons for their failures, usually caused by different cultural expectations between the participants. Critical incidents encourage students to reflect on the analyzed situation and help them develop a range of strategies for effective cross-cultural communication. They are useful in probing the cultural assumptions people make in interactions with foreigners. They seem to sensitize learners to cultural differences and develop their intercultural sensitivity and competence (Triandis, 1995a; 1995b). Critical incidents might be useful in helping students develop mediating skills, since they might result in some discomfort or even conflict. This in turn will require learners to mediate between different sides of the conflict. Yet, the explored books offer the learners no training in conflict mediation, either.

The cultural input of the examined books does not give learners much access to reflecting on their own values, attitudes, and beliefs, nor on the ones of strangers (11 times). The distribution of this exercise category in the sample ranges from one to five. However, in 15 of the books, such tasks do not appear at all (75\% of the sample).

The frequency of another intercultural activity type, namely, interpreting visual and verbal cultural representations, is even smaller-in the whole sample there have been only five recordings. Such exercises can be found in only five books ( $25 \%$ of the sample) and only once in each. This shows that the examined textbooks will not prepare the students to analyze how messages are constructed and understood across cultures. 
Non-verbal communication is practiced in the sample even less frequently - in fact, two recordings have been made in only two textbooks, i.e., in the majority of the sample $(90 \%)$, nothing is done to make the students aware of the differences in this area of intercultural communication.

No exercises designed to work on students' socio-cultural pragmatic competence have been found in the sample. Accounting for the importance of this sphere of language, signaled in the introduction, such deficiency is a serious drawback of the examined textbooks. If learners are to produce situationally appropriate utterances, they have to be able to determine what can be said, to whom, where, when, and how. Such practice in a FL classroom is extremely important, since pragmatic competence in our native language is a powerful influence working against the appropriate use of a FL.

The cultural content of the examined books reflects a culturalist perspective. Culture is presented in a very traditional, old-fashioned way, as if it were homogenous and static. It is reduced to a body of factual knowledge about a particular country or a cultural domain. This is done uncritically and with limited involvement between the learner and the culture being presented. The learner is positioned as an external observer of cultural facts, rather than as someone expected to interpret cultural practices considered relevant to increase this learner's capacity to communicate in a FL. Students passively consume the information about natural wonders, prominent architecture, regional food and dances, etc.

The message the cultural sections convey is rather superficial and lacks in-depth analysis of the presented content. Students do not have any opportunity to go beyond static appraisals of the presented material, because it does not encourage them to pursue deeper interpretation. Neither questions nor activities accompanying the texts stimulate the learners to think more deeply, or analyze their feelings, interpretations, and responses.

For example, one can find texts about Hollywood movies and television programs, such as The Simpsons, Big Brother, American Idol, Deal or No Deal, Celebrity Homes, and the HBO series The Sopranos, A Space Odyssey, The Lord of the Rings, Avator (a breakthrough in 3D sci-fi movies), or Melancholia. There are also many excerpts from literary works, mainly passages from English or American novels, such as Sherlock Holmes, The Portrait of Dorian Grey, Oliver Twist, Tess of the d'Urbevilles, The Great Gatsby, 1984, The Time Machine, The Life and Adventures of Nicholas Nickleby, and Frankenstein, and a short poem by Robert Burns.

There is quite a large representation of architectural icons in the sample, mainly from the English-speaking countries, for example, Stonehenge, the Sydney Opera House, the Sydney Harbor Bridge, the White House, the Statue of Liberty, the Tower of London, Buckingham Palace, Windsor Castle, or York Cathedral. But examples of architectural icons from other cultural areas can be found, too, such as the Taj Mahal, the Eiffel Tower, or the Wieliczka Salt Mine Chapel. The sample presents a lot of tourists' attractions, mainly from Western, English regions, e.g., Beverly Hills, downtown New York, Harrods, Yellowstone National Park in the U.S., or the Karijini National Park in Australia, and foods (examples range from European cuisine, such as pizza, fish and chips, and reindeer stew, to quite exotic dishes, like edible caterpillars popular in some African regions, aquatic insect larvae enjoyed in Japan since ancient times, or grasshoppers eaten in Mexico). However, the authors seem to have adopted a tourist's perspective, emphasizing how much there is to see and do in the places presented. Thus, they turn the students into tourists who travel from country to country and do not engage themselves with the cultures met.

The books in the sample depict customs from around the entire world. Among them, learners will find those well-known, originating from the Western culture, such as Christmas in the U.S. with its gingerbread 
cookies and a Christmas tree, St. Patrick's Day, Mardi Gras in New Orleans, Burn's Night in Scotland, to those less known, e.g., the Burning Man Festival in Nevada, the U.S. (alternative arts festival), dog sled races in the Cascale mountains of the northern U.S., or pumpkin throwing competition in Delaware, U.S.. The analyzed textbooks also present customs typical of non-English speaking countries, illustrated by a celebration of the religious feast of Corpus Christi in the Polish context, where church goers follow the priest in a procession of the Blessed Sacrament displayed in a monstrance along the streets of the city, or the lemon festival in Menton, in southern France, where people make a lot of lemonade and create amazing giant statues using tons of lemons and oranges.

The sample also presents customs from non-European backgrounds, such as the Chinese New Year or the Jewish Hanukkah, or Kwanzaa - a holiday to commemorate African heritage. Students will find information about daily life in various places around the globe. For example, they will read about different aspects of education (home schooling in Great Britain and the U.S., a system of education in Great Britain, English independent and boarding schools, college life in the U.S., the Ivor Spencer International School of Butler Administrators, schools in Poland, Harvard University, and career counseling typical of the U.S.), sport (American football as illustrated by the Super Bowl, golf, rugby, cricket, the London marathon), and teenagers (summer jobs in the U.S.) and society in the broad sense. The latter is depicted by the texts about unconventional housing which brings people back to nature (a tree house in West Sussex in England, a boathouse, a house in a double decker bus, and reed houses in Peru), new forms of employment (teleworking), shopping malls (the U.S.), unusual places (a chill-out ice restaurant in Dubai), picking up litter on a beach in Brighton (Litter Day), and the Edinburgh Festival.

Learners will find in the materials various rites of passage, ranging from getting a driver's license at the age of 16 in the U.S., through a child's going off into the wilderness to get guidance and direction for the future in Native American tribes, to arranged weddings in India. However, what the material is missing is a chance for students to make comparisons, explore cultures on their own and draw conclusions that there are no universal solutions. For example, users of Matura Prime Time Plus (Intermediate) can learn a lot about arranged marriages in India and a Hindu wedding ceremony, but the material does not invite them to discuss how people enter into marriages across the globe and what reasons lie behind what differs cultures in this respect.

The cultural content is limited, fragmented, and superficial. For example, in the material on sport, usually only one is described (e.g., American football or golf), whereas basketball, quite common in America, is not mentioned in any of the samples. Cultures are presented as being only slightly different and the differences between them are often obscured. Kramsch's (1987) claim that textbooks are often developed with reference to the culture of the learner rather than to that of the target community still seems to be valid. This is done to protect students from the perceived discomfort of encountering different ways of living and of viewing the world. Consequently, cultural diversity is not presented as a normal element of human reality with its own internal validity and value, but as something that is to be assessed from one's own cultural perspective. Unfortunately, this way students' intercultural understanding is fostered in a very limited way, if at all.

Cultural sections of the examined textbooks present a range of views typical of particular cultures. It is illustrated by Crime Scene Investigation, a popular drama series in the U.S., perceived by viewers as entertainment and not a source of real crime evidence. Views are also depicted in an informative text about American TV series (both found in Oxford Matura Trainer [Advanced]). Those TV series mirror the changes which have taken place in society over the years. For example, students learn how the perception of fatherhood 
in the 20th century changed, from unrealistic, autocratic fathers who had their jobs and did nothing at home, but read newspapers and watched TV (Father Knows Best), through fathers of blended families (The Cosby Show), who shared economic and parenting responsibilities, to immature dads who needed more care than their children (The Simpsons). ABC's Modern Family breaks ground by portraying a same sex couple who struggle with adoption and fatherhood. However, in the whole sample, there is only one such example presenting a particular view in a broader perspective (Oxford Matura Trainer [Advanced]).

The sample books present diverse attitudes towards various aspects of life across the globe, e.g., how Brits perceive charity - from the text Red Nose Day, learners get to know that it is a big charity event that has become a sort of holiday of laughter in which many people want to participate. A lot of special comedy shows are organized on TV and viewers can call in to make donations (Matura Prime Time Plus [Pre-intermediate]). The text Sculptures Under the Sea depicts a unique example of the environment protection done by an artist in Cancun. He encourages tourists to swim to the underwater sculpture park he created which is supposed to be an alternative to a visit to a damaged reef (Matura Prime Time Plus [Pre-intermediate]). Another text (Care Homes) shows Americans as an uncaring society who put their elderly in nursing homes (Matura Trainer [Advanced]). However, the text is very judgmental and subjective - only one side of the coin is presented. The reason for which nursing homes are so popular, i.e., focusing on an individual's independence, has not been mentioned.

The analyzed books contain a lot of information about people — national and international icons, figures who symbolize or represent people in a country as a whole, and heroes whose qualities, track records, and accomplishments demand national or even international respect and admiration. In the sample, students will find people of different walks of life, such as Frida Kahlo, Edgar Allan Poe, Ralph Lauren, Lady Gaga, and Mark Beaumont (a Scottish cyclist with an entry in the Guinness World Records book). They will read about a Mexican poet Octavio Paz (the winner of the 1990 Nobel Prize in literature), Mother Teresa (born in Macedonia and founder of the Missionaries of Charity Order), or Usain Bolt (a runner from Jamaica, who holds eight world championship titles).

Almost half of the icons presented in the textbooks originate from English-speaking countries, but quite a number of them stem from Western cultures that are non-English speaking. They are mostly Polish, which is determined by the course books targeting the Polish students. Among the people displayed in the sample are Bronisław Malinowski, an inspiring, world-famous anthropologist; Lech Wałęsa, the icon of the Solidarity movement and the first president elected in democratic elections; Wisława Szymborska, a well-known poetess and Noble Prize winner; and Janina Ochojska, the founder of a charity organization.

Those people offer a considerable potential for intercultural exploration in the classroom because they embody qualities admired by a group, nation, or international community. However, this potential for intercultural exploration has not been utilized - there are no follow-up activities which could motivate students to express their opinions on the qualities those icons are considered to have, or examine how well they mirror the core values of the nation they stem from, or the qualities that the nation as a whole finds admirable. Nor are students encouraged to try to reflect on the qualities that have made some of those individuals iconic figures across nations and cultures.

Very useful for intercultural communication seem to be tips on etiquette in such diverse places as Thailand, Dubai, Egypt, Rio, or Germany found in the textbooks. However, they can be found only in the minority of them. 


\section{Conclusion}

The research reported in the article has revealed that the examined EFL textbooks' capacity to develop students' intercultural sensitivity and competence is very low. Out of 10 activity types identified as crucial for fostering intercultural skills, four have not been found in the sample at all. Although students have some opportunities to explore foreign cultures, they do this very superficially and mostly indirectly, merely by reading texts. The most useful exercises, i.e., ethnographic projects, have not been included. Students contrast and compare cultures, but it happens even less frequently. Furthermore, the most useful tasks for developing intercultural competence, namely, critical incidents, do not appear in the sample.

Students compare cultures with their own, but since it is done very superficially, one can doubt whether such exercises will contribute to showing students the subjectivity of cultural norms, conventions, and people's behaviors. No tasks involve students with mediation across cultures, nor the developing of their socio-pragmatic abilities. The books do not involve learners in discovering the importance of the interplay between speakers in creating meaning, which is strongly conditioned by the cultural context. Similarly, very few exercises, if any, designed to work on non-verbal communication in different cultures and interpreting visual and verbal cultural representations, can be found in the examined books. Students will have not many opportunities to reflect on values, attitudes, and beliefs.

The cultural material in the analyzed textbooks seems to have been presented in a fragmented way. The materials seem to be disconnected from each other, making it impossible for the students to realize how multi-dimensional culture is and often invisible on the surface, thus difficult to describe. Such a simplified approach to culture which students will face obscures its complexity and makes teaching/learning it very ineffective, which might result in many misunderstandings in future intercultural encounters.

The cultural content most frequently found in the sample revolves around topics connected with entertainment, tourist attractions, food, and literature. Such a choice might result from textbook writers' incorrect assumption that such popular topics are more appealing to the target audience and can stimulate more interest in them than abstract ones inviting students to analyze diverse beliefs, attitudes, or religions.

Intercultural perspective is hardly visible in the examined material and, consequently, the users will not be prompted to develop open-mindedness toward cultural diversity, mindfulness, or respect for otherness. Although there is a wide range of culture representations in the sample, this does not automatically contribute to fostering students' intercultural competence, since developing it does not require many cultures to be present. What are needed instead are specially designed activities motivating learners to explore, contrast, and compare cultures, which in the case of the examined books is missing.

Some limitations of the present study should be addressed since they provide agenda for future research. The findings obtained provide a crude picture of teaching culture in the sample. To help validate the current analysis, more detailed qualitative investigation should be undertaken. It will increase the credibility of interpretations and provide a more reliable answer to the research questions.

\section{References}

Byram, M. (1988). Foreign language education and cultural studies. Language, Culture and Curriculum, 1(1), 15-31.

Council of Europe. (2001). Common European framework of reference for languages: Learning, teaching, assessment. Cambridge, U.K.: Cambridge University Press.

Dignen, B., \& Chamberlain, J. (2009). Fifty ways to improve your intercultural skills. London, U.K.: Summertown Publishing. 
Kohls, L., \& Knight, J. (1994). Developing intercultural awareness: A cross-cultural training handbook. Yarmouth, Me: Intercultural Press.

Kramsch, C. (1993). Context and culture in language education. Oxford, U.K.: Oxford University Press.

Kramsch, C. (1987). Foreign language textbooks' construction of foreign reality. Canadian Modern Language Review, 44(1), 95-119.

Kramsch, C. (2008). Ecological perspectives on foreign language education. Language Teaching, 41(3), 389-408.

Liddicoat, A., \& Scarino, A. (2013). Intercultural language teaching and learning. Hoboken, N.J.: Wiley-Blackwell.

Sobkowiak, P. (2012a). Cross-cultural perspective of FL teaching and learning in the Polish context. Studies in Second Language Learning and Teaching, 2(4), 527-541.

Sobkowiak, P. (2012b). Dialog interkulturowy na lekcji języka angielskiego w kontekście polskim (Intercultural dialog in the EFL classroom in Poland). Neofilolog, 38(1), 107-128.

Sobkowiak, P. (2013). Intercultural dimension of FL teaching in the Polish context. In M. Kleban, \& E. Willim (Eds.), PASE papers in linguistics (pp. 291-309). Kraków: Jagiellonian University Press.

Sobkowiak, P. (2014). Intercultural teaching in the Polish context. In M. Pawlak, J. Bielak, \& A. Mystkowska-Wiertelak (Eds.), Classroom-oriented research: Achievements and challenges (pp. 185-202). Cham, Heidelberg, New York, Dordrecht, London, U.K.: Springer.

Sobkowiak, P. (2015). Interkulturowość w edukacji językowej (Intercultural language education). Poznań: Adam Mickiewicz University Press.

Triandis, H. (1995a). Culture-specific assimilators. In S. Fowler, \& M. Mumford (Eds.), Intercultural sourcebook: Cross-cultural training methods (Vol. I, pp. 179-186). Yarmouth, M.E.: Intercultural Press.

Triandis, H. (1995b). Individualism and collectivism. Boulder, C.O.: Westview Press.

\section{Appendix: Investigated Textbooks}

Dooley, J., \& Evans, V. (2014a). Matura prime time plus (Elementary). Newbury: Express Publishing.

Dooley, J., \& Evans, V. (2014b). Matura prime time plus (Pre-intermediate). Newbury: Express Publishing.

Dooley, J., \& Evans, V. (2014c). Matura prime time plus (Intermediate). Newbury: Express Publishing.

Dooley, J., \& Evans, V. (2014d). Matura prime time plus (Upper-intermediate). Newbury: Express Publishing.

Dummett, P., Benne, R. R., Inglot, M., \& Polit, B. (2015). New Matura explorer (Upper-intermediate). Warsaw: Nowa Era.

Falla, T., \& Davies, P. A. (2011a). New Matura solutions (Elementary). Oxford: Oxford University Press.

Falla, T., \& Davies, P. A. (2011b). Matura solutions (Pre-intermediate). Oxford: Oxford University Press.

Falla, T., \& Davies, P. A. (2012). Matura solutions (Intermediate). Oxford: Oxford University Press.

Falla, T., \& Davies, P. A. (2013). New Matura solutions (Upper-intermediate). Oxford: Oxford University Press.

Goldstein, B. (2005). Framework (Pre-intermediate). London: Richmond Publishing.

Harding, R., Markowska, M., Sosnowska, J., \& Szuwart, J. (2014). Oxford Matura trainer. Repetytorium z języka angielskiego. Poziom rozszerzony (Matura exam preparatory course [Advanced level]). Oxford: Oxford University Press.

Hughes, J., Polit, B., Wardyńska, E., \& Michalak, I. (2014). New Matura explorer (Intermediate). Warsaw: Nowa Era.

Hughes, J., Łubecka, A., \& Polit, B. (2015). New Matura explorer (Elementary). Warsaw: Nowa Era.

Jones, C., \& Goldstein, B. (2005). Framework (Elementary). London: Richmond Publishing.

Manin, G., Gryca, D., Sobierska, J., \& Sosnowska, J. (2014). Oxford Matura trainer. Repetytorium z języka angielskiego. Poziom podstawowy (Matura exam preparatory course [Ordinary level]). Oxford: Oxford University Press.

Naunton, J., Łubecka, A., \& Polit, B. (2014). New Matura explorer (Pre-intermediate). Warsaw: Nowa Era.

Oxenden, C., Latham-Koenig, C., \& Seligson, P. (2005a). New English file (Elementary). Oxford: Oxford University Press.

Oxenden, C., Latham-Koenig, C., \& Seligson, P. (2005b). New English file (Pre-intermediate). Oxford: Oxford University Press.

Oxenden, C., \& Latham-Koenig, C. (2006). New English file (Intermediate). Oxford: Oxford University Press.

Oxenden, C., \& Latham-Koenig, C. (2008). New English file (Upper-intermediate). Oxford: Oxford University Press. 